\title{
DOES THE WORLD STILL NEED US?
}

Under this title, an article by General Torstein Dale, President of the Norwegian Red Cross, published in the League of Red Cross Societies' publication Panorama (1972/4), raises a number of questions of importance for the Red Cross and related to its position and role in today's world. Some significant excerpts are quoted below:

... Like it or not, a climate of competition has developed among the various voluntary organizations and between them and official authorities, national and international.

Red Cross cannot ignore these rivalries and it cannot hope to survive with an outdated organization. We must reorganize our international structure and step up our efficiency...

... In the Nordic countries, as in others, the "welfare state" has assumed responsibility for the entire population and ensures that no-one lives in misery. In theory there should be no need for voluntary help nationally. However, many individuals and groups of people have found themselves overlooked or uncatered for. The need for voluntary help has not disappeared; on the contrary it has frequently increased...

... Both political and voluntary action are necessary; it would be absurd and immoral to stop voluntary work and use people in need as a lever to force greater government action.

The voluntary organizations must act as pioneers, take initiatives, organize services and then let the government take over, while they move on to new areas of need. 


\section{IN THE Red CROSS WORLD}

The idea of the State as an omnipresent " protective coating " is becoming increasingly widespread. The individual feels that as a taxpayer he is entitled to pass on responsibility for those in need to the State. As a result of this reasoning old people live and die in isolation, invalids are abandoned, victims of assault ignored, traffic victims refused transportation.

A growing "dehumanization" is taking hold of our society. It represents a major challenge for voluntary organizations. They must not only serve as effective channels for public help; they must also actively encourage the development of a feeling of solidarity among people, a feeling of responsibility towards one's fellowmen.

But solidarity must exist as a reality and not just as fine words. We must begin with ourselves and with our own organization. We must in fact return to one of the basic ideas of the Red Cross movement and build our work on this ideological concept. If we can recapture the spirit of those pioneering days I think we can make a major contribution to society.

Practically, what can we do? First, develop an organization which, nationally and internationally, allows us to carry out quickly and effectively tasks based on the notion of solidarity...

In conclusion, the President of the Norwegian Red Cross expressed the hope that the League and the ICRC would co-operate on a broader basis and that the fundamental Red Cross concepts would be expressed in a language which reaches all our contemporaries. The ICRC, for its part, is pleased at the work already undertaken towards the fulfilment of that wish. 